\title{
Hybrid Historiography: Pre- and Post-conquest Latin America and Perceptions of the Past
}

Carolyn Salomons, University of Alberta

According to Michel de Certeau, historiography is a paradoxical word, "almost an oxymoron", which attempts to connect two antinomic terms: "history" and "writing", and where that connection cannot be imagined, of functioning as if they are connected. ${ }^{1}$ Yet the discipline of History (as created by and in Europe) is so firmly rooted in the written word and in the structure of narrative that it has often been difficult to imagine the event without that corresponding narrative. ${ }^{2}$ Thus, comparative historiography can become an unbalanced project for it almost always entails the comparison of "traditional" Eurocentric historiography with something "Other". The "Other" in the equation are those places and cultures that until recently were labelled ahistorical, as though without a written history recognizable to European eyes, there was no history at all. This is not to say that such cultures were unconcerned with the past, but rather that their understanding of the past was not fixed within the confines of European historiographical standards. Historiography as understood within Eurocentric notions of the discipline obviously presupposes a written text, which instantly creates a gap historians have not been able to close - that between the real and the discourse representing the real. The struggle to contain an

\footnotetext{
${ }^{1}$ Michel de Certeau The Writing of History trans. Tom Conley (New York: Columbia University, 1988) xxviii.

${ }^{2}$ When I say that History was created by and in Europe, I am speaking of History as a social science, the Rankean idea that history can be truthful, objective, based solely on facts, and allow us to understand "what essentially happened" in the past. 
event within the confines of a written text is artificial and plastic; meaning is entrenched not only in authorial intention, but also in interpretation. ${ }^{3}$ Comparative historiography of such disparate societies, then, becomes even more plastic as difference in cultural referents blurs this interpretation

However, the comparison of the "historical" with the "ahistorical" is not an impossibility, especially given recent trends within the discipline of History to re-examine and question the traditional notions of historiography. ${ }^{4}$ If we put aside Eurocentric notions of what historiography is, we see that the differences between the ahistorical and the historical are less obvious. One place where such a comparison lends itself is post-conquest Latin America. The historiography of post-conquest Latin America offers a compelling site in which to investigate such issues. Examining perceptions of the past in pre- and post-conquest Latin America reveals not merely linkages or appropriations between two differing historical points of view, but also shows us that this encounter shaped and changed historical perceptions, creating what seem to be new, hybrid perceptions of the past. These hybrid historiographies, however, might be less a new creation than a removal of Enlightenment, Eurocentric notions of History which allows space for somewhat transcendental commonalities in how societies view the past to emerge.

\footnotetext{
${ }^{3}$ By interpretation I do not mean to suggest that causality, consequence and meaning of historical events are solely determined at the discretion of the historian, but rather that a historian's worldview - her or his position in the world as determined by class, race, gender, religion, etc. - will necessarily impact on his or her narrative. Such subjectivity is unavoidable in historiography; no matter how objective a historian presupposes her or himself to be.

${ }^{4}$ See, for example Hayden White's questioning of narrative in The Content of the Form: Narrative Discourse and Historical Representation (Baltimore: Johns Hopkins, 1987). For a brief overview of late twentieth century debates and controversies within the field, see Keith Jenkins Re-Thinking History (London: Routledge, 1991). 
Carlos Fuentes believes that Latin Americans have an uneasy relationship with their past. He claims that they are "worried about redeeming the past"; that the past "is still battling for [their] souls". ${ }^{5}$ The legacy of conquest, imperialism and colonialism certainly seems (on the surface) to loom larger in the Latin American conscious than in the North American. This can be explained by a number of factors, the most obvious being the difference in colonizer. Is there something peculiar then, about Spain and its process of conquest and its administration of colonial rule that has left its former colonies with an embattled sense of their past? I would argue that there is. The year 1492 was momentous in Spanish history: it marks both the "discovery" of a "new world" and the completed reconquista of the old one. These two factors played upon each other as the spaniards spread through Latin America, and informed their thinking about the people they meet there.

The arrival of the Spaniards brought a new language, a new religion, a new philosophy about the world. The Latin American Subaltern Studies Group, among others, feel that these constructs were imposed upon indigenous cultures, that the European idea of a "new world" inherently presupposed a blank page upon which the Europeans wrote. ${ }^{6}$ I in no way wish to argue the domination of

\footnotetext{
${ }^{5}$ Carlos Fuentes, Latin America, At War with the Past (Montreal: CBC Enterprises, 1985), 2. I do not mean to suggest that Carlos Fuentes has the definitive perspective on Latin American history, however, his statement does offers one (especially given the scope of this paper) interesting viewpoint on what history means to modern Latin Americans.

6 "Founding Statement" Latin American Subaltern Studies Group, boundary 2, Vol. 20, No. 3 (Autumn, 1993), 110-121. This group appropriates South Asian notions of the subaltern, and its lack of speaking space, as explicated by Gayatri Spivak's article, "Can the Subaltern Speak?" in Cary Nelson and Larry Grossberg, eds. Marxism and the Interpretation of Culture. (Chicago: University of Illinois Press, 1988), 271-313. Cf. José Rabasa, Inventing America: Spanish Historiography and the 
European culture in this space, and certainly, "pure" indigenous cultures have been eradicated through this contact. However, to maintain that this domination bolsters Hegel's notion that "modern Christian Europe" had nothing to learn from indigenous cultures, and everything to teach, (i.e. civilize) is to deny cultural transference. ${ }^{7}$ Certainly, as I will examine below, there is evidence 4 of indigenous writers co-opting European methodology, yet careful readings of these texts reveal an import relevant to indigenous cultures, meaningless to Europeans. In addition, readings of Spanish texts also reveal that the writers were not unaffected by their encounter with a "new world" and a "new people". Amerindian perceptions of the past crept into post-conquest histories, perhaps unwittingly. Possibly it was a by-product of the translation process, either from oral history into written, or from indigenous languages into Spanish. Yet we cannot overlook the idea of Amerindian agency in constructing their own versions of the past, including not only the events of the conquest, but also of pre-conquest time. In fact, histories written decades or even a century post-conquest maintained and mingled both Amerindian and European perceptions of the past. Therefore, choosing to speak of a "discovery", an "invasion", or an "invention" of a new world is perhaps not very useful when comparing historiographical traditions. To do so negates any power Amerindian cultures had on the Spanish, and ignores the transformative effect that this intersection of cultures had on all involved.

Formation of Eurocentrism (Norman, Oklahoma: University of Oklahoma Press, 1993) ch. 2, "Columbus and the new Scriptural Economy".

${ }^{7}$ See Enrique Dussel's paper "Eurocentrism and Modernity", boundary 2, Vol. 20 No 3. The Postmodern Debate in Latin America (Autumn 1993) 65-76, esp. 67. 


\section{Pre-Conquest Indigenous Perceptions of the Past}

One paramount difference between European and Amerindian historiography lies in cultural perceptions of the past. For European historians, the past is a place of death and absence, fixed and unchangeable. ${ }^{8}$ Time is also an absolute - a linear and often teleological progression. Historiography then necessarily becomes something fixed and unchangeable as well. For Amerindian societies, the past was less fixed, less unchangeable, not necessarily linear nor teleological. Examining Amerindian perceptions of past time will help us understand their ways of formulating history.

Remnants of Aztec culture remain with us today, enough to gain some small understanding as to how this culture perceived the past. However, as Ross Hassig points out, what we know of them depends entirely on our interpretations of these remnants. ${ }^{9}$ Part of the problem stems from Western interpretations of time; not only the Western preference for linear over cyclical time, but also time as an absolute. Certainly there is much evidence, most obviously the Aztec calendar system, which points to a cosmology rooted in cyclical patterns of time. ${ }^{10}$ Yet reducing Aztec perceptions of time to endlessly repeating eras is naïve. We must also disengage from Western "persistence in looking at time as an abstraction" and instead, reorient ourselves towards time as it really is lived. ${ }^{11}$ All complex societies have notions of both linear and cyclical time;

\footnotetext{
${ }^{8}$ de Certeau, 46.

${ }^{9}$ Ross Hassig, Time, History and Belief in Aztec and Colonial Mexico (Austin: University of Texas, 2001), 6 .

${ }^{10}$ The Aztec calendar is extremely complicated and requires more space than I here have at my disposal for explication. See Hassig, Time, History and Belief, esp. Ch. 1 and 3.

${ }^{11}$ Hassig, Time, History and Belief, 61.

Past Imperfect 12 [2006] | (C) |ISSN 1192-1315
} 
the Aztecs were no exception. ${ }^{12}$ For example, the agricultural year was understandably recognized as cyclical, so too was the religious year, with festivals and events reoccurring at set times. However, Aztecs also perceived a linear progression through life, evidenced by the recognition of fifty-two as the age of retirement. In addition, they also viewed political life as linear, no doubt due to its 6| unpredictability and randomness. ${ }^{13}$ Events such as the coronation of kings, building of temples and natural occurrences such as comets or earthquakes all were conceived as linear occurrences. ${ }^{14}$ However, the Aztecs had no linear time frame linked to their calendars (such as the Western practice of dating $B C$ and $A D$, now often seen as BCE and $\mathrm{CE}$ ), which made it difficult for Europeans to transpose Aztec history into their own linear time frame. ${ }^{15}$ Thus, Europeans came to categorize Aztec historiography as cyclical and therefore incomprehensible to Western historians. Incomprehensibility, however, is probably more rooted in the inherent difference between Aztec and European perceptions of time.

This is evidenced by what Hassig calls Aztec "manipulation" of time. The calendar was of paramount importance, and certain dates are imbued with omens of good or ill. Since this society was one with no mechanical markers of time, time became elastic rather than absolute. ${ }^{16}$ On both the individual

\footnotetext{
${ }^{12}$ Ibid. See also Nancy M. Fariss, "Remembering the Future, Anticipating the Past: History, Time, and Cosmology among the Maya of Yucatan" Comparative Studies in Society and History No 3, Vol 29, 1987, 566-593 for a discussion of the concept of time amongst the Maya.

${ }^{13}$ Hassig, Time, History and Belief. 61-62.

${ }^{14}$ Ibid., 110-111.

${ }^{15}$ Anthony F. Aveni and Edward E. Calnek "Astronomical Considerations in the Aztec Expression of History: Eclipse Data” Ancient Mesoamerica Vol. 10 (1999), 89.

${ }^{16}$ Ibid., 36.
} 
and the official level, time could be and was manipulated. ${ }^{17}$ This is a conception also found in other indigenous cultures of Latin America and as it was so foreign to European understandings of time that difficulties on both sides in comprehending the history of the other are unsurprising. The Andean sense of history, for example, is also categorized as cyclical. Frank Salomon writes that it demands not a chain, but a pattern of events. ${ }^{18}$ Andean historical thought is explicated as embodying the property of "eternal return" with the idea that similar events temporally distanced were "renewed sightings of constant points". ${ }^{19}$ While there is no doubt that cycles and patterns were of paramount importance in the Andean historical tradition, we must again look at the Andean conception of time. As Salomon points out: "The Andean world knew no absolute yardstick of time measured from a conventional starting point" ${ }^{20}$ Here we see the same elasticity of time as evinced in the Aztec historical tradition.

Joanne Rappaport, in her explication of the historical tradition of the Nasa, a people of the highlands of Colombia, finds

\footnotetext{
${ }^{17}$ Ibid., 36-47. On an individual level, for example, if a child's birthday was ill omened, the parents could consult the calendar and choose an auspicious naming day, which would then serve as the child's birthday. Hassig gives several instances of time manipulation on the official level, one of the most interesting being the New Fire ceremony, which marks the beginning of new Calendar Round of 52 years. In the pre-Aztec era, it was celebrated in 1Tochtli, the Aztecs, however, celebrated the ceremony in the year 2 Actal. Obviously, there was some temporal shift between the time of the Toltecs and the arrival of the Spaniards. Hassig has several theories as to why this was - perhaps the Aztecs suffered too many military defeats during 1 Tochtli; there is also evidence that 1506 (the most recent 1 Tochtli) was a famine year. The Aztecs could very well have thus decided to shift the ceremony to a more propitious year.

${ }^{18}$ Frank Salomon "Chronicles of the Impossible: Notes on Three Peruvian Indigenous Historians" From Oral to Written Expression: Native Andean Chronicles of the Early Colonial Period ed. Rolena Adorno (Syracuse N.Y.: Maxwell School of Citizenship and Public Affairs, Syracuse University, 1982), 10/

${ }^{19}$ Ibid., 11.

${ }^{20} \mathrm{Ibid}$. 
another interpretive sense of the past. She explains that Nasa histories differed from European in their narrative structure which was brief, sometimes episodic, proverbial or lyric. ${ }^{21}$ History for the Nasa, then, was not "lodged in a static text", but rather in the "ongoing process of interpretation". 22 In addition, these accounts often were not chronological, and ignore what is 8| paramount for Western historiography: causal relations, distinct time-frames, and a linear format. ${ }^{23}$ This does not mean, Rappaport argues, that the Nasa had no sense of causation or of linear time, however, these notions were conveyed in a different context and mode rather than embedded in the narrative itself.

This interpretive approach to history was enhanced by the pictoideographic writing system of many of these cultures. Walter D. Mignolo explains that in the Aztec language, Nahuatl, the verb "to read" does not exist. ${ }^{24}$ The closest word is amoxitoa, a combination of "bark" or "tree" (writing material) and "narrate". ${ }^{25}$ Reading, then, was not simply understanding the meaning of the signs on the "page", but also interpreting them. The reading of history thus changes with each interpreter (narrator). ${ }^{26}$ While Mignolo admits to some surmising on this point, he is correct in maintaining that while the content of the narration was stable, the form certainly was not. This changeable form is unacceptable by Western historiographical standards, which are rooted in alphabetic writing; and as such, deemed fixed and unchangeable. It

\footnotetext{
${ }^{21}$ Joanne Rappaport The Politics of Memory: Native Historical Interpretation in the Colombian Andes (Durham, North Carolina: Duke University Press, 1998), 11.

${ }^{22}$ Ibid.

${ }^{23} \mathrm{Ibid}$.

${ }^{24}$ Walter D. Mignolo The Darker Side of the Renaissance: Literacy, Territoriality and Colonization (Ann Arbor: University of Michigan, 2001), 132.

${ }^{25}$ Ibid.

${ }^{26}$ Ibid., 133.
} 
is not that surprising that Spaniards (such as Juan de Torquemada or Juan de Mariana) who encountered indigenous "historiography" failed to recognize it as such. ${ }^{27}$

Although it is a mistake to assume perceptions of the past were universal amongst pre-conquest indigenous populations, this interpretive approach was common. According to Ashis Nandy, this different way of constructing the past renders Amerindian societies ahistorical, by Western historical standards. ${ }^{28}$ When the two encounter one another, Nandy maintains that the main option has been to transform the ahistorical into the historical, with only one "weak alternative": the attempt to recover the "repressed historical self" of the ahistorical society. ${ }^{29}$ However, even this notion of a repressed historical self is transformative. The recovery of such a self speaks to the acknowledgement of the "quasi- or proto- historical" nature of the ahistorical society. ${ }^{30}$ This seems quite similar to the difficulties encountered by subaltern studies if the subaltern is by definition a peripheral object, what happens when this periphery attempts to gain space in the centre? The subaltern is not capable of hegemonic action, says Ranajit Guha, and thus, can never succeed in becoming "centred". ${ }^{31}$ Therefore, both efforts - to historicize the ahistorical and to centre the periphery - are doomed from the start. Rather than attempting to locate constructions of European Enlightenment history within a

\footnotetext{
${ }^{27}$ Ibid., 133 See also Deborah Root "The Imperial Signifier: Todorov and the Conquest of Mexico" Cultural Critique, No. 9, (Spring, 1988), 197-198.

${ }^{28}$ Ashis Nandy "History's Forgotten Doubles" History and Theory 34:2, (May, 1995), 44. Nandy's concept of ahistorical societies is arrived at by comparing them (for him, India) with European Enlightenment ideas about history, a comparison I maintain for this paper.

${ }^{29}$ Ibid., 44-45.

${ }^{30}$ Ibid., 45.

${ }^{31}$ Ranajit Guha, "On Some Aspects of the Historiography of Colonial India" Selected Subaltern Studies, (Oxford, 1988), 37-43.

Past Imperfect 12 [2006] | (C) | ISSN $1192-1315$
} 
supposedly ahistorical place; rather than dismissing such histories as "pre-historical, primitive or pre-scientific", as Nandy claims Western historians do; and rather than assuming that the only way to access these histories is through a transformative process, perhaps we need to unpack post-encounter histories to search for the effects of the encounter on both historical traditions ${ }^{32}$. What the 10| project begs for, then, is locating these histories outside of European Enlightenment history altogether, in what at first glance appears to be a hybrid space, but possibly is simply something more authentic, more like "time as it is really lived" than traditional European historiography is.

\section{Spain - History, Language and Unity}

The first century post-conquest did see a debate amongst the Spaniards as to whether the Amerindians had "History". We have seen how Amerindian conceptions of the elasticity of time led the Spaniards to question their perceptions of the past. In addition, this debate was also rooted in the pictoideographic style of Amerindian "writing" - a culture without an alphabet. ${ }^{33}$ From a post-Rankean perspective, we immediately understand the problem. In Western historiographical traditions, time is not elastic, and the written word is privileged over all other forms of communication. However, the Spaniards of the sixteenth century were not Rankeans, and yet there was a strong reaction against these indigenous ideas about the past. Juan de Torquemada wrote:

\footnotetext{
${ }^{32}$ Ibid., 44.

${ }^{33}$ Walter D. Mignolo "Literacy and Colonization: The New World Experience" 14921992: Re/Discovering Colonial Writing ed. René Jara and Nicholas Spadaccini (Minneapolis: University of Minnesota, 1989), 76. 
One of the things which causes the most confusion in a republic and which greatly perplexes those who wish to discuss its causes, is the lack of precision with which they consider their history; for if history is an account of events which are true and actually happened and those who witnessed them and learned about them neglected to preserve the memory of them, it will require an effort to write them down after they happened, and he who wishes to do so will grope in the dark when he tries, for he may spend his life collating the version which he is told only to find that at the end of it he still has not unravelled the truth. This (or something like this) is what happens in this history of New Spain, for just as the ancient inhabitants did not have letters, or were even familiar with them, so they neither left records of their history. ${ }^{34}$

For the Spaniards, no alphabet meant no history. More so than other European nations, Spain was at a certain point in its own history where language became imbued with a unique and weighted sense of meaning. We look to October 18, 1469 - the date of the marriage of Isabel of Castile and Fernando of Aragón, and for many the birth date of Spain as a Nation-State. ${ }^{35}$ The unification of these two kingdoms put an end to centuries of fragmentation, a fragmentation which ostensibly began with arrival of the Muslims

${ }^{34}$ Juan de Torquemada, Monarquia Indiana (Mexico: Editorial Porrua, S.A., 1969) Book 1, Ch. 11. trans Walter D. Mignolo.

${ }^{35}$ Antonio Gómez-Moriano, "Narration and Argumentation in the Chronicles of the New World" 1492-1992: Re/Discovering Colonial Writing ed. René Jara and Nicholas Spadaccini (Minneapolis: University of Minnesota, 1989), 99. I am very aware of the anachronistic problem of Gómez-Moriano's use of the term "Nation-State"; however, I feel the idea behind the term is useful. Retrospectively, the union of Castile and Aragón marks the beginning of an unprecedented unity on the peninsula. While 1469 does not see a fully formed Nation-State spring to life, this is the root of Spain as we know it today. Ashis Nandy notes that the collusion between the discipline of History and modern narratives of citizenship and nation-state makes it that much more difficult to separate the two. Nandy, "History's Forgotten Doubles", 53.

Past Imperfect 12 [2006) | ( ) | ISSN $1192-1315$ 
in the seventh and eight century. ${ }^{36}$ Small states, both Christian and Islamic, fought for territory and in doing so, formed, broke, and re-formed alliances. All that was at an end, and in 1492, the last Islamic kingdom, Grenada, surrendered to los Reyes Católicos. It was also in 1492 that Antonio de Nebrija published the first Castilian grammar book. In his dedication, to Queen Isabel, Nebrija 12| maintained that the Castilian language was a "companion of the empire" which consolidated "the scattered members and pieces of Spain". ${ }^{37}$ Importantly, not only language unites, but also religion: "the enemies of our faith have been vanquished" and now "there is nothing left but the flowering of the arts of peace. Among the first ones is that which language teaches us". ${ }^{38}$ This was a nation formed under the banner of religious struggle, which lived through a crusade against "infidels", who were formerly neighbours and allies. ${ }^{39}$ The conquistadores carried this crusade mentality with them to the "new world". ${ }^{40}$

\section{Intersection: The "Other" encounters the "Other"}

Fray Bartolomé de Las Casas was one whose conquistador mentality was reshaped by his encounter with the "new world". ${ }^{41}$ The son of a

\footnotetext{
${ }^{36}$ To believe that the arrival of the Muslims is what caused disunity in the Iberian peninsula is to buy into the corresponding belief that prior to their arrival there was an essential "Spanish" character, which survived centuries of exposure to Islamic culture intact. Américo Castro dispels this notion in The Spaniards: an Introduction to Their History (Berkeley, University of California, 1971).

${ }^{37}$ Antonio de Nebrija, Gramatica de la Lengua Castellana (Oxford, 1926), 5-6.

${ }^{38}$ Ibid., 6.

${ }^{39}$ Antonio Gómez-Moriana "Narration and Augmentation", 102.

${ }^{40}$ Enrique Dussel "Eurocentrism and Modernity" boundary 2, 1993, 67.

${ }^{41}$ A caveat: the Spanish accounts of the "new world" are almost always regarded as histories although none of the men who wrote them were historians per se. Most of these accounts were written by soldiers, bureaucrats and in this case, a priest. While some of these works do have historical narratives within them, Las Casas is far more concerned with the present than the past in his writings. I should also 
noble family of Sevilla, he arrived in America in 1502 in search of wealth. Ten years later, he was a Dominican friar advocating "Indian rights". ${ }^{42}$ Historians approach him with caution; they are uncertain what to make of his writings. ${ }^{43}$ One of his works was published in his lifetime: his Brevíssimia relación de la destrucción de las Indias - a polemical work with which Las Casas buttressed his case for reformed laws regarding Amerindians and slavery. He also wrote the Apologética historia sumaria, an ethnological treatise, and was working on a more general Historia de las Indias, of which the former was to be a part, when he died. ${ }^{44}$ Las Casas had benefited from an excellent humanist education, and perhaps because of this, historians hope to find in him as objective a voice as possible. However, his Brevissimia is regarded by many with suspicion, owing to its overt bias against the Spanish. ${ }^{45}$

note that the writers included in this project are only a selection of a larger group, chosen to be representatives rather than the definitive collection.

${ }^{42}$ Angel Delgado-Gomez Spanish Historical Writing about the New World: 1493-1700 (Providence: The John Carter Brown Library, 1992), 55.

${ }^{43}$ See, for example, the differing views of René Jara and Nicholas Spadaccini, who acknowledge his advocacy for the fair treatment of indigenous persons, while at the same time must admit his agenda of overt Christian evangelization, which had no room for allowing those indigenous persons to practice the religions of their own cultures. "Introduction: Allegorizing the New World" 1492-1992: Re/Discovering Colonial Writing ed. René Jara and Nicholas Spadaccini (Minneapolis: University of Minnesota, 1989), 18-19.

${ }^{44}$ A. Curtis Wilgus, The Historiography of Latin America: A Guide to Historical Writing, 1500-1800 (Metuchen, New Jersey: The Scarecrow Press, 1975), 19; Rabasa Inventing America, 169. Las Casas' work is associated with English Protestant propaganda against Catholics, the "Black Legend" of Spanish activities in the "new world". His work was published in seventeenth century England under the title: Casas' horrid massacres, butcheries, and cruelties that hell and malice could invent committed by the Spanish in the West Indies. Delgado-Gomez, Spanish Historical Writing, 56.

${ }^{45}$ Wilgus, The Historiography of Latin America p. 18. Despite this, his contemporary, Alfono Fernandez, paints a glowing portrait of Las Casas as one who "speak[s] like a saint, inform[s] like a jurist, give[s] judgments like a theologian, and testifie[s] as an eye witness" quoted in Rolena Adorno "Arms, Letters and the Native Historian" 1492-1992: Re/Discovering Colonial Writing ed. René Jara and Nicholas Spadaccini (Minneapolis: University of Minnesota, 1989), 209. 
However, Beatriz Pastor finds Las Casas maintaining his adherence to "objectivity" when he described Christopher Columbus' interpretation of indigenous communication: "He had already made up his mind. Thus, everything the Indians would say to him in sign language ... he would twist the meaning and attribute it to what he desired." ${ }^{46}$ We see Las Casas did the same in 14| his own works: José Rabasa examines them for references to the Americas as being, and the Amerindians as inhabiting, a utopian, mythical and prelapsarian state. ${ }^{47}$ His writing is replete with such imagery:

... these people are the most guileless, the most devoid of wickedness and duplicity, the most obedient and faithful. . . . They are by nature the most humble, patient and peaceable, holding no grudges, free from embroilments, neither excitable or quarrelsome. These people are the most devoid of rancors (sic), hatreds or desire for vengeance of any people in the world. . . . they not only possess little but have no desire to possess worldly goods. For this reason, they are not arrogant, embittered or greedy. ${ }^{48}$

Rabasa argues that such imagery, on the surface complimentary, is part of the "invention" of America by the Europeans. Placing Amerindians in such a paradigm materializes a "mythical locus", in effect, rendering the real mythical, or imaginary. ${ }^{49}$ This, Rabasa claims, is as equally destructive as those Spaniards who Las Casas so

\footnotetext{
${ }^{46}$ Beatriz Pastor, "Silence and Writing: The History of the Conquest" 1492-1992: $\mathrm{Re} /$ Discovering Colonial Writing ed. René Jara and Nicholas Spadaccini (Minneapolis: University of Minnesota, 1989), 128.

${ }^{47}$ Rabasa, Inventing America, 169-170.

${ }^{48}$ Bartolomé de las Casas, The Devastation of the Indies: A brief account trans. Herma Briffault (Johns Hopkins University, 1974), 28.

${ }^{49}$ Rabasa, Inventing America, 169.

Past Imperfect 12 [2006] | (C) ISSN 1192-1315
} 
vehemently attacked in his work. In fact, for Las Casas to title his work an account of a "destruction" is in itself part of the problem. Whatever it is that was destroyed, was first invented by Las Casa, and without that invention, there could be no destruction. ${ }^{50}$

We cannot ignore the fact that Las Casas did indeed create the people who populate his work. Did he see them as real, or were they mere representations of something? The latter seems more likely. However, to criticize him for this construction is also problematic. We must remember that he was describing lands and people without precedents, and he was doing so in a milieu that did not know how to deal with unprecedented histories. ${ }^{51}$ Europe looked to the past for meaning; for Las Casas to use mythical and Biblical language to describe what to him seemed, in many ways, paradisiacal, is hardly unexpected. If he was careless in his descriptions, if his work was peopled with two-dimensional characters, we perhaps ought to forgive him, for he had no other tools by which to describe, and yes, invent this "new world".

Juan de Betanzos wrote a very different type of history. A Spaniard who spent most of his adult years in the "new world", was fluent in Quecha and married the former wife of Atahualpa (who was at one time the mistress of Francisco Pizarro), he was also regarded as a somewhat prejudiced historian, but unlike Las Casas, he was not accused of polemics. ${ }^{52}$ However, Betanzos' motivation for writing what he called his "narrative" stemmed from an anthropological rather than a historical interest. His prologue speaks to this: "I realized how differently the conquistadores speak about [the acts and customs of the Incas] and how far they were

${ }^{50}$ Rabasa, Inventing America, 166.

${ }^{51}$ Delgado-Gomez, Spanish Historical Writing, 3

${ }^{52}$ Wilgus, The Historiography of Latin America, 66

Past Imperfect 12 [2006] | (C) | ISSN $1192-1315$ 
from [understanding] what the Indians did". ${ }^{53}$ This lack of understanding was rooted in the language barrier; Betanzos believed he could overcome the barrier by explicating Incan customs and traditions. ${ }^{54}$ To begin his project, he turned to Incan history.

Betanzos' sources were the Incans themselves - his wife 16| and her family, as well as other Incan elders. His narrative, then, was a translation both from Quechua into Spanish, and from oral into the written. ${ }^{55} \mathrm{He}$ was aware of the difficulties inherent in such a project, and noted that he must "respect the style and order of speech" of the natives. He also noted that what he was told was "factual" and yet at the same time, he commented on the custom of the Incans to "say whatever they imagine or dream". ${ }^{56}$ Within his work, it is unclear how he determined the imaginary from the factual, save for his constant use of the expression "they say" when recounting the mythical origins of the Incas ${ }^{57}$ His text begins here, in a time of total darkness, with the emergence of the divine being, Contiti Viracocha, who created the sun, moon and stars, and then a people made from stone. These he sent out into the four directions. ${ }^{58}$ Betanzos, however, at the end of this chapter, discounted the story by labelling it a "beastly, pagan, and barbarous idolatry". ${ }^{59}$ Yet he continued in this mythical vein, with the story of the founding of Cuzco - an account which narrates how four couples emerged from the earth, made their way to the Valley of

\footnotetext{
${ }^{53}$ Juan de Betanzos Narrative of the Incas trans. and ed. Roland Hamilton and Dana Buchanan (Austin: University of Texas, 1996), 3.

${ }^{54}$ Ibid.

${ }^{55}$ Ibid.

${ }^{56}$ Ibid., 4.

${ }^{57}$ Ibid., ch I-II.

${ }^{58}$ Ibid., 7-10.

${ }^{59}$ Ibid., 11
} 
Cuzco (one of them knocking down mountains with his slingshot and creating ravines along the way), and ends with the investiture of another of these as the first Inca, Manoc Capac. ${ }^{60}$ He then followed the course other Spanish historians of the Incas followed the histories of the twelve Incas, the expansion of the territory from the first to the ninth Inca, and the creation of the Incan empire over the reigns of the last three Incas, the same empire which the Spanish encountered in $1531 .^{61}$ This methodology conforms closely to European historical antecedents, where all history is thought to begin at a point of origin, and continues progressively until the present. ${ }^{62}$ Such origins are allowed to contain aspects of the supernatural, or divine agency, which gradually diminished the closer the story gets to the present. For the Spaniards, the Bible recounts their point of origin, and thus Betanzos has no difficulty in including the supernatural in the Incan origin story, although he had to discount it as "pagan".

Betanzos claimed to be a translator of Incan history, admittedly attempting to capture Incan linguistic style in his writing. Yet Sabine MacCormack finds his history troubling; she maintains it is "too Spanish" to be authentic. ${ }^{63}$ Her claim stems not only from the above mentioned belief in a point of origin from which history progress, but also from the Spanish perception (found in other histories besides Betanzos) that there was an Incan dynasty of twelve rulers succeeding through male primogeniture. In fact, male primogeniture is not an Andean tradition, and, more

\footnotetext{
${ }^{60}$ Ibid., 13-16.

${ }^{61}$ Sabine MacCormack, "History, Historical Record and Ceremonial Action: Incas and Spaniards in Cuzco" Comparative Studies in Society and History 43:2 (April, 2001), 332

${ }^{62}$ Ibid.

${ }^{63}$ Ibid., 331.
} 
importantly, this chronology of twelve is questionable.$^{64}$ She bases this on the idea that twelve is a significant number to the Europeans (twelve tribes of Israel, twelve signs of the zodiac), but that it has no such weighted meaning for the Incas. ${ }^{65}$ There is evidence that the Incas were prone to give answers to questions shaped by what they believe the Spaniards wanted to hear; perhaps 18| this was a similar occurrence. ${ }^{66}$ In addition, we must remember the ceremonial aspect of Incan history. In its oral form, it had a performative and ritualistic component. Much of what Betanzos learnt about the origins of the Incas he very likely saw performed in various ceremonies. MacCormack describes such a ceremony that took place in March 1534: the inauguration of the last Incan ruler, Manco Inca Yupanqui. As part of this ceremony, the embalmed bodies of previous Incan leaders were carried in the procession, not only to signify the continuation of the royal line, but also to remind the new leader of the tradition whence he came and to look to the past for instruction in how to govern. ${ }^{67}$ Such recitations were continuously edited, to mask shameful deeds and to highlight glorious ones. ${ }^{68}$ This means, then, that the lives of each Incan ruler blur into one another, creating yet more problems when one tries to separate them into twelve distinct characters.

Betanzos was sympathetic to the Incas; he truly wanted to explain who they were to a European audience, and this is apparent in his writing. But as a Spaniard attempting to translate Incan

\footnotetext{
${ }^{64}$ Ibid., 331-332.Curiously, although MacCormack faults Betanzos for adhering to the notion of the twelve Incan rulers, Betanzos is unique amongst his contemporaries in that he lists thirteen rulers - he includes Yamque Yupanque, who did not actually rule, but was heir to his father until he stepped aside for his brother, Topa Inca Yupanque. Betanzos, Narrative of the Incas Part 1, Ch. 25-27.

${ }^{65}$ MacCormack "History, Historical Record and Ceremonial Action", 331-332.

${ }^{66}$ Ibid., 335.

${ }^{67}$ Ibid., 330.

${ }^{68}$ Ibid., 331.
} 
history, his own perceptions of what History is informed his text. Did he include everything he should? Did he, consciously or not, mask the importance or significance of certain events? Did he highlight things that were not meaningful in the Incan cosmology? He was on the outside looking in, and attempting to understand what he saw. His account of the conquest of Peru speaks to this. He was one of the victors, and his tone in recounting, for example, the massacre of Incas at the time of Atahualpa's capture is noticeably dispassionate. In addition, Atahualpa is painted as an ineffectual leader who needed rescuing by Pizzaro himself:

While the Inca was in the condition that you have heard [drunk], the marquis Francisco Pizarro came through the Indians and the rest of the Spaniards and reached the Inca and took him from the litter and removed him from the multitude of Indians and Spaniards who were coming at him. He carried him to his lodgings. By the time he reached the Inca, many of his troops had reached him, too, and wanted to kill him. In his attempt to defend him, the marquis was wounded in one hand by the swords that were meant for the Inca. Thus he defended him and in this way the Inca Atahualpa was taken prisoner in Cajamarca. ${ }^{69}$

Though Betanzos wanted explain the Incas to the Spaniards, he could never remove himself from his own perception of the world to do so. He maintained his belief in the civilizing influence of the Spaniards on the Incas: there are references to the Incas as a

${ }^{69}$ Betanzos Narrative of the Incas, 265.

Past Imperfect 12 [2006]| (C) |ISSN 1192-1315 
rebellious people "in the wild" who were rightly placed "under the royal dominion and crown of Spain". ${ }^{70}$

In contrast to Betanzos, there is an indigenous history, similar in scope, yet containing certain marked differences. Guaman (or Huamán) Poma's Letter to a King was written specifically to tell the history of the Incas, the conquest of Peru and the 20l post-conquest treatment of the Incas by the Spaniards, all from the Incan point of view. ${ }^{71}$ Guaman Poma. by his own account, was descended from Incan royalty, brought up in the Christian faith, and spent much of his career as a translator and interpreter - a liason between the indigenous population and the Spanish. Although his history covers roughly the same events as Betanzos, there are striking differences in content. Since Letter to a King was written from the Amerindian perspective, one might expect a similar version of the mythical origin story as related by Betanzos, so obviously peopled with Incan mythical characters. However, Guaman Poma's account ignored that version, and instead he positioned the origins of the Incas within a Christian narrative:

The first white people in the world were brought by God to this country. They were descended from those who survived the Flood in Noah's Ark. ... The white people knew the institution of marriage and lived peacefully with one another. They learnt the skills of ploughing and sowing, in the simple way in which these had been practised by Adam and Eve.... However barbarous they may have been, our ancestors had some

\footnotetext{
${ }^{70}$ Ibid., 299-301. I must note that the reference to "in the wild" comes after the fall of Cuzco, and presumably these are the Incas who chose to leave their city in the hopes of an autonomous life elsewhere.

${ }^{71}$ Don Felipe Guaman Poma de Ayala Letter to a King: A Peruvian Chief's Account of Life Under the Incas and Under Spanish Rule ed. and trans. Christopher Dilke.(New York: E.P. Dutton, 1978), 19-20.
} 
glimmer of understanding of God. Even the mere saying of the name Pachacamac is a sign of faith and an important step forward. Christians have much to learn from our people's good way of life. ${ }^{72}$

Why would Guaman Poma not only appropriate a foreign historical methodology but also a foreign origin myth? This is evidence of what Walter Mignolo calls the "tension of the past, which Amerindians needed to remember, fix and transmit [using] models of writing history from a tradition . . . not their own". ${ }^{73}$ Far from being subsumed by European modes of historiography, Amerindians were adapting and in some cases, subverting those modes in order to preserve their own sense of the past. Yet rather than simply giving a different account of verifiable events, Guaman Poma "fictionalized" the conquest through a hypothetical verbal structure. He was not merely adding his voice, his perspective, to the canon of conquest historiography, he was also "attempt[ing] to make sense of a past long gone and a present that seem[ed] to deny the very existence of that lost era". ${ }^{74}$ The only way that Guaman Poma could complete such a project was by appropriating what seemed to him to be the dominant mode of discourse, and with that, the dominate mythical scheme - in this case, the Christian narrative.

Guaman Poma's account shares the "standard" chronology of the twelve Inca rulers with Betanzos, the same chronology that Sabine MacCormack criticized Betanzos for using. ${ }^{75}$ Rolena Adorno suggests that he was merely "paying lip service" to European

\footnotetext{
${ }^{72}$ Ibid., 24-25.

${ }^{73}$ Mignolo, The Darker Side of the Renaissance, 204 emphasis mine.

${ }^{74}$ Ibid.

${ }^{75}$ Guaman Poma Letter to a King, 32-47.

Past Imperfect 12 [2006] | (C) | ISSN $1192-1315$
} 
historical chronology here; what is more important is the "synchronic description of Andean society" ${ }^{76}$ Recalling the ritualistic and performative aspects of Inca history, the kings become archetypes instead of individuals, and what matters is not who they were but what they represent.

Difference between Guaman Poma and Betanzos is also 22| evident in the narrative of the capture of Atahualpa by the Spaniards. There is no mention of drunkenness, or ineffectuality on the part of Atahualpa. Instead, we are told of the amazement and astonishment on the part of the Incas at the sight of men dressed in metal armour and on horses. There was panic, and fear, but Atahualpa remained dignified and in control of himself. ${ }^{77}$ A most intriguing scene is the one where Friar Vicente calls upon the Incas to embrace Christianity:

Atahualpa's reply was that he could not change his belief in the Sun, who was immortal, and in the other Inca divinities. He asked Friar Vicente what authority he had for his own belief and the friar told him it was all written in the book which he held. The Inca then said: 'Give me the book so that it can speak to me'. The book was handed up to him and he began to eye it carefully and listen to it page by page. At last he asked: 'Why doesn't the book say anything to me?' Still sitting on his throne, he threw it on the ground. .. ${ }^{78}$

Note the verbs Guaman Poma used. The friar speaks of writing, but Atahualpa approaches the book according to his own custom,

\footnotetext{
${ }^{76}$ Rolena Adorno “The Language of History in Guaman Poma's Nueva corónica y buen gobierno" From Oral to Written Expression: Native Andean Chronicles of the Early Colonial Period ed. Rolena Adorno (Syracuse N.Y.: Maxwell School of Citizenship and Public Affairs, Syracuse University, 1982), 111.

${ }^{77}$ Guaman Poma Letter to a King, 108-109.

${ }^{78}$ Ibid., 109, emphasis mine.
} 
attempting to discover meaning through speaking and listening. Like the Aztecs, the Incas had no alphabet, but pictures and symbols had great meaning, although they needed to be interpreted. ${ }^{79}$ Atahualpa disparaged the text because it did not speak to him and there was no one who could interpret it.

What are we to make of these differences and similarities between the two texts? Is Guaman Poma a more reliable source because he comprehended Incan perceptions of the past? Or is Betanzos more reliable because he was an "objective" outsider? As we have already seen, Betanzos is problematic owing to the gap between him and his subject, a gap not only of the cultural differences between the written and the oral, but also the differences in language. Is Guaman Poma equally problematic, or can he overcome such differences in historical methodology?

From the outset, a Western historian would indeed find Guaman Poma's work problematic, and for more reasons than the differences noted above. Time was not a fixed absolute for Guaman Poma; there is a plethora of examples that show the elasticity, and indeed, the collapse of time in his writing. According to Guaman Poma, Christ was born during the reign of the Second Inca, Sinchi Roca Inca - which is surmised to have occurred circa 1200. It was also during this reign that St Bartholomew "arrived from Jerusalem" ${ }^{80}$ There are other instances of invention in the work: the account of his father's reception of Pizarro and Almagro, and the Andeans welcome of the authority of Charles II are two such examples. ${ }^{81}$ Does this mean that Guaman Poma is to be discounted entirely? Adorno argues not. She maintains that truth is a

\footnotetext{
${ }^{79}$ Rolena Adorno “The Language of History”, 115-122.

${ }^{80}$ Guaman Poma Letter to a King, 37, 104.

${ }^{81}$ Rolena Adorno Guaman Poma: Writing and Resistance in Colonial Peru, 14 
combination of both fact and the "conceptual matrix" within which the discourse is located. To explicate what this means in terms of Guaman Poma's work we must regard Letter to a King as not a "litany of historical detail" but rather a postulation of an intricate hypothesis. $^{82}$

If we recall both Andean conceptions of time, and the quote 24) from Mignolo above (when he claims that Amerindians need to fix the past), Guaman Poma's hypothesis begins to become clarified. Guaman Poma did not refer to the conquest as a pachacuti, which, in Andean cosmology, is the anticipated destruction of the universe that divides epochs of history. ${ }^{83}$ Such a term he might conceivably have used, since the Incan world was demonstrably destroyed. Rather, he used the concept of a "world upside down" to describe the post-conquest era. The people have "lost all sense of direction. They forgot their gods and missed the authority of their rulers; and no justice or religion was yet imposed by the Christians" ${ }^{84}$ Guaman Poma was reluctant to allow his world to be eradicated; he had to find some place within this "new world" for himself. For the Amerindians, just as much as for the Spanish, these events were unprecedented and they also were searching for ways to render these events into language. Las Casas borrowed the language of myth and Biblical tropes of paradise for his history; Guaman Poma used European terms to describe what he witnessed. There were no Andean words for him to use. ${ }^{85} \mathrm{He}$ attempted to combine European historiographical methodology with his own Andean sense of time.

\footnotetext{
${ }^{82} \mathrm{Ibid}, 15$.

${ }^{83}$ Adorno, "The Language of History", 111. This word is used when he describes the civil war between the Incan brothers Huascar and Atahuallpa which preceded the conquest - signifying that this event was yet a part of the old order.

${ }^{84}$ Guaman Poma, 111.

${ }^{85}$ Adorno "The Language of History", 112. 
What remains, then, is his compelling account of the conquest not simply from the point of view of the Andeans, but from the point of view of a new and adapted cosmology. The liberties he took with the conventions of European historiography were not problematic in his eyes.

But let us look to another post-conquest indigenous history, to determine if Amerindian cosmology did marry European historical constructions, or if Amerindian historians simply positioned themselves within the dominant discourse. Fernando de Alva Ixtilxochitl is called the "American Cicero" because of his eloquent style. ${ }^{86}$ His writings are deemed "erudite and impressive" and are used as a source for Spanish historians writing about the "new world" ${ }^{87}$ However, Alva Ixtlilxochitl was not Spanish, but mestizo - descended from both the Aztec and the Texcoca cultures, a direct descendent of Prince Ixtlilxochitl. Herein lay the motivation for Alva Ixtilxochitl's work. He was writing in a space in which Rolena Adorno claims the native aristocracy was attempting to "Hispanize" themselves as much as circumstances allowed. ${ }^{88}$ Despite this, the sources Alva Ixtlilxochitl relied on were indigenous, not Hispanic. Ballentine admires his "extensive knowledge of the antiquities of his nation", 89 Alva Ixtlilxochitl had access to these because he could read the painted amoxtli ${ }^{90}$ and understood the oral histories and memories of his elders. ${ }^{91}$ His work, then, became more than a translation from Nahuatl into

\footnotetext{
${ }^{86}$ Wilgus, The Historiography of Latin America, 144.

${ }^{87}$ Douglass K. Ballentine ed. Ally of Cortes (El Paso: Texas Western Press, University of Texas, 1969), xv.

${ }^{88}$ Rolena Adorno, “Arms, Letters”, 210.

${ }^{89}$ Ibid., xv.

${ }^{90}$ amoztli is the Aztec term for the material on which painted narratives were inscribed.

${ }^{91}$ Mignolo The Darker Side of the Renaissance, 93. 
Spanish; he was also translating the Aztec cosmology or sense of history into a European methodology. He was careful to cite his authorities, and since he could not allow them to remain ignorant (albeit noble) savages, he specifically outlined the methodology by which the Aztecs recorded their history, covering it with a veneer of European scholarly sophistication. ${ }^{92}$

26| Writing almost one hundred years after Cortes arrived in Mexico, Alva Ixtlilxochitl was very aware of the importance of Christianity to the Spaniards, and therefore his appropriation of the conquistador tradition in his work is highly significant. In his account of the conquest of Mexico, Alva Ixtlilxochitl portrayed Prince Ixtlilxochitl as a soldier of God. Thus, rather than one who achieved the "melancholy glory" of betraying his own people, he is refashioned as an early convert to Christianity, who hoped to reclaim his own land from the "barbarian" Aztecs. ${ }^{93}$ When other local Kings accused him of fighting against his own people, he responded that "he preferred to be a friend of the Christians who brought with them the true light, and that its profession was very good for the health of the soul". ${ }^{94}$ He welcomed the group of Franciscan friars who arrived in 1524 with "great rejoicing" and tears of happiness and devotion.$^{95}$ He taught his family Christian doctrine, and "did this in such a way that he melted them with words so good and so holy that they might have come from an apostle, if that can be said". ${ }^{96}$ In Alva Ixtlilxochitl's history, it was Cortés who was the betrayer. This is contrary to many Spanish

\footnotetext{
${ }^{92}$ Ibid., 95-96.

${ }^{93}$ Fernando de Alva Ixtilxochitl Ally of Cortes ed. Douglass K. Ballentine (El Paso: Texas Western Press, University of Texas, 1969), xiii-xiv.

${ }^{94}$ Ibid., 24.

${ }^{95}$ Ibid., 74-75.

${ }^{96}$ Ibid., 77.
} 
histories of Cortés, who attribute "bravery and prudence" to the man. ${ }^{97}$ According to Adorno, Alva Ixtlilxochitl appropriated the heroic figure - in essence, pulling the "Christian warrior culture over to his side, and ... [filling] that reorganized space with heroic actions and actors that were entirely missing from Spanish accounts of the same episodes ... of the Mexican conquest. At the same time, he had to reduce to an absence the image of Mexican sacrificial society as "non-culture"" ${ }^{98}$ His work, offered as an alternative but couched in European language and rhetoric, spoke primarily to his realization of having been silenced as a subject. The only way he felt able to speak was with a European voice, yet what he said, his ability to go back and "rewrite" the past was rooted in his Amerindian sense of history and the elasticity of time.

The Spanish histories not only promoted Cortés as a brave and capable leader, they also diminished the role of the Amerindian allies in the conflicts of the conquest. ${ }^{99}$ In light of this, it may seem that Alva Ixtlilxochitl was simply offering his (subjective) version of the undisputed events of the conquest. We do not see the same plasticity of events as we did in Guaman Poma. Is Alva Ixtlilxochitl a hybrid historian then, or merely appropriating European methodology and discourse? One could argue that he was simply voicing the role of the indigenous people in Cortés' fight against the Aztecs, a role most Spanish historians ignored in their desire to emphasize the military ability of their own people. However, there are aspects of Alva Ixtlilxochitl's history which are imbued with traditional values. More than simply acknowledging the role of Prince Ixtlilxochitl as Cortés' ally, and constructing him in some

${ }^{97}$ Adorno, “Arms, Letters", 211.

${ }^{98}$ Ibid., 210-211.

${ }^{99}$ Ibid., 212-213.

Past Imperfect 12 [2006] | (C) | ISSN 1192-1315 
sense as a conquistador, Alva Ixtlilxochitl was also writing the story of a worthy indigenous leader. Prince Ixtlilxochitl became leader of the Texcocoans in place of Ahuaxpictzoctzin at the request of the people because "he was so brave, because all the natives had great respect for the quality of his person . ..". ${ }^{100}$ Indigenous militarism was not ritualistic, as many European historians have understood 28 it. It was a way to acquire noble status, and Alva Ixtlilxochitl's method by which to salvage the reputation of his ancestor and his own position as a colonial subject. ${ }^{101}$ However, these pre-conquest values were compromised through their rendition into the language and context of Spain. This compromise does not deny any legitimacy; rather it reiterates the blurring of identities within the space of the "new world". ${ }^{102}$ No longer a "neat model of binary opposition", we instead have what Adorno calls a "third or intermediate type of alterity" - a hybrid identity, which in turn posits a hybrid historiography. ${ }^{103}$

\section{Conclusions: Hybrid Historiography}

Looking to history, to historiography, to find "truthful" accounts of the past places asks much of the discourse, for in the postmodern academic world, historic "truth" is regarded with great suspicion. Even so, from a post-Rankean standpoint, we may well want to dismiss these Amerindian historians as "imperfect imitations of European texts". ${ }^{104}$ However, that ignores the mutuality of the encounter. The problem is that until recently, agency was always in

\footnotetext{
${ }^{100}$ Alva Ixtilxochitl Ally of Cortes, 15.

${ }^{101}$ Adorno, "Arms, Letters", 214, 218.

${ }^{102}$ Ibid., 216.

${ }^{103}$ Ibid.

${ }^{104}$ Rabasa, Inventing America, 13.
} 
European hands - Europe invents America, America does not invent Europe. Or rather, there is Amerindian agency, but because it does not conform to Eurocentric paradigms, it remains unheard: the subaltern unable to speak. But can we not see that Europe, by inventing America, invents Europe? Rabasa sees this point in time as the root of Eurocentrism, for Eurocentrism cannot exist without its "Other" ${ }^{105}$ I do not believe a "re-invention" of America is called for, nor is one possible. It no longer matters if the historians were truthful or objective, it no longer matters if the invention of America is "right" or "wrong'; it is.

Enlightenment history cannot accept what Ashis Nandy calls the "principle of principled forgetfulness". ${ }^{106}$ This type of history values unpacking of the past, laying bare the past, but only with a "neatly articulated frame of reference that implicitly involves a degree of demystification or demythologization". ${ }^{107}$ Without this frame of reference, history devolves into myth. Therefore when we read Guaman Poma or Alva Ixtlilxochitl, we might feel troubled, since both subscribed to this "forgetfulness" by rewriting their pasts. They principally forgot the European histories written about their people and principally remembered what the Europeans either did not hear, or perhaps also "forgot". It becomes too easy, then, to dismiss Guaman Poma and Alva Ixtlilxochitl as unreliable sources, as writers of myth instead of history, as purveyors of what should have been, rather than what was. Where is truth, and who speaks it?

\footnotetext{
${ }^{105}$ Ibid., 8. See also Arif Dirlik "History Without a Center?: Reflections on Eurocentrism" Across Cultural Borders: Historiography in Global Perspective ed. Eckhardt Fuchs and Benedikt Stuchtey (Lanham, Maryland: Rowman \& Littlefield, 2002), 257.

${ }^{106}$ Nandy, "History's Forgotten Doubles", 47.

${ }^{107}$ Ibid., 48. 
The problem with trying to ascertain who speaks the truth is that it assumes an accurate and somehow "real" America against which both Spanish and Amerindian historiography can be measured. ${ }^{108}$ That America, however, lies in that gap of which Michel de Certeau spoke: the gap between the real and the discourse. Since the limitations of the project are obvious 30| factuality is not argued, but rather the "ground of factuality itself" - alternatives are called for. José Rabasa advocates foregrounding the "hybridity" of colonial texts, by not simply adopting a "menu of [poststructuralist or postcolonial] methods" but by questioning the very underpinnings of methodology: "experiment with [the] propositions, question [the] epistemological grounds, suspend claims to universality and taunt requirements of theoretical purity or demands of consistency". ${ }^{109}$ At first glance, such a proposition seems to dovetail with Ashis Nandy's call for an alternative to history itself. I would argue a difference. Rather than discard the discipline entirely, what we need is an awareness of the hybrid nature of history. Yes, the study of history as a discipline was born in Europe, but perceptions of the past are global. The attempt to articulate what historiography represents outside of Europe immediately slips into a comparative analysis: similarities and dissimilarities between European and non-European history. (Again, Eurocentrism positioned against an "Other"). Arif Dirlik claims that this is an inevitability; since History is European, Europe cannot be factored out of any analysis of historiography. ${ }^{110}$ He goes on to posit that the challenge to history is not globalization (the realization and acceptance of "other" histories outside of

\footnotetext{
${ }^{108}$ Rabasas, Inventing America, 6.

${ }^{109}$ Ibid., 14-15.

${ }^{110}$ Dirlik, 276.
} 
Eurocentrism) but the attempt to "accommodate the global and the place-based [local] in simultaneous mutuality". ${ }^{111}$ Is there not some way in which an overarching umbrella of History can contain histories? It seems as though the historiographers of post-conquest Latin America are attempting exactly this. Since mutual reciprocity informs their perceptions of the past, they articulate just such a hybrid historiography, drawing on both Eurocentric and Amerindian methodology. Acknowledging Guaman Poma and Alva Ixtlilxochitl as authentic historians and allowing their accounts of the past to stand with las Casas' and Betanzos' as worthy of scholarly study is indeed beneficial. The resulting accounts provide us with different locations from which to view the past, still not able to bridge de Certeau's gap, still not able to experience the past as it actually was, but with a much richer understanding of the various perceptions and interpretations of the discourse about the real.

\section{Bibliography}

Primary Sources

Alva Ixtlilxochitl, Fernando de, Ally of Cortes ed. Douglass K. Ballentine (El Paso: Texas Western Press, University of Texas, 1969).

Betanzos, Juan de Narrative of the Incas trans. and ed. Roland Hamilton and Dana Buchanan (Austin: University of Texas, 1996).

Nebrija, Antonio de Gramatica de la Lengua Castellana (Oxford, 1926).

Guaman Poma de Ayala, Felipe Letter to a King: A Peruvian Chief's Account of Life Under the Incas and Under the Spanish Rule trans. Christopher Dilke, (New York: E.P. Dutton,1978).

${ }^{111}$ Ibid., 279.

Past Imperfect 12 [2006] | (C) | ISSN 1192-1315 
Las Casas, Bartolomé de The Devastation of the Indies: A brief account trans. Herma Briffault (Johns Hopkins University, 1974).

Harper, 1971).

History of the Indies trans. and ed. Andrée M. Collard (New York:

Torquemada, Juan de Monarquia Indiana (Mexico: Editorial Porrua, S.A., 1969)

Book 1.

$32 \mid$

\section{Secondary Sources}

Adorno, Roleno "Arms, Letters and the Native Historian in Early Colonial Mexico" 1492-1992: Re/Discovering Colonial Writing ed. René Jara and Nicholas Spadaccini (Minneapolis: University of Minnesota, 1989), 201-224.

Guaman Poma: Writing and Resistance in Colonial Peru (Austin: University of Texas, 2000).

“The Language of History in Guaman Poma's Nueva Corónica y Buen Gobierno" From Oral to Written Expression: Native Andean Chronicles of the Early Colonial Period ed. Rolena Adorno (Syracuse N.Y.: Maxwell School of Citizenship and Public Affairs, Syracuse University, 1982), 109-133.

Aveni, Anthony F. and Edward E. Calnek "Astronomical Considerations in the Aztec Expression of History: Eclipse Data” Ancient Mesoamerica Vol. 10 (1999) 87-98.

Certeau, Michel de The Writing of History trans. Tom Conley (New York: Columbia, 1988).

Delgado-Gomez, Angel Spanish Historical Writing About the New World: 1493-1700 (Providence: John Carter Brown Library, 1992).

Dirlik, Arif "History Without a Center?: Reflections on Eurocentrism" Across Cultural Borders: Historiography in Global Perspective ed. Eckhardt Fuchs and Benedikt Stuchtey (Lanham, Maryland: Rowman \& Littlefield, 2002), 247-284.

Fuentes, Carlos Latin America: At War with the Past (Montréal: CBC Enterprises, 1985).

Gómez-Moriana, Antonio "Narration and Argumentation in the Chronicles of the New World" 1492-1992: Re/Discovering Colonial Writing ed. René Jara and Nicholas Spadaccini (Minneapolis: University of Minnesota, 1989), 97-120.

Hassig, Ross Time, History and Belief in Aztec and Colonial Mexico (Austin: University of Texas, 2001).

Past Imperfect 12 [2006] | (C) | ISSN 1192-1315 
MacCormak, Sabine "History, Historical Record and Ceremonial Action: Incas and Spaniards in Cuzco" Comparative Studies in Society and History 43:2 (April, 2001), 329-363.

"History and Law in Sixteenth-Century Peru: The Impact of European Scholarly Traditions" Cultures of Scholarship ed. S. C. Humphreys, (Michigan, 1997), 277-310.

Mignolo, Walter D. The Darker Side of the Renaissance: Literacy, Territoriality and Colonization (Ann Arbor: University of Michigan, 2001).

"Literacy and Colonization: The New World Experience" 1492-1992:

Re/Discovering Colonial Writing ed. René Jara and Nicholas Spadaccini (Minneapolis: University of Minnesota, 1989), 51-96.

Nandy, Ashis "History’s Forgotten Others" History and Theory 34:2 (May, 1995), 44-66.

Pastor, Beatriz "Silence and Writing: The History of the Conquest" 1492-1992: Re/Discovering Colonial Writing ed. René Jara and Nicholas Spadaccini (Minneapolis: University of Minnesota, 1989), 121-163.

Rabasa, José, Inventing America: Spanish Historiography and the Formation of Eurocentrism (Norman, Oklahoma: University of Oklahoma Press, 1993).

Rappaport, Joanne, The Politics of Memory: Native Historical Interpretation in the Colombian Andes (Durham, North Carolina: Duke University Press, 1998).

Root, Deborah "The Imperial Signifier: Todorov and the Conquest of Mexico" Cultural Critique, No. 9, (Spring, 1988), 197-219.

Salomon, Frank, "Chronicles of the Impossible: Notes on Three Peruvian Indigenous Historians" From Oral to Written Expression: Native Andean Chronicles of the Early Colonial Period ed. Rolena Adorno (Syracuse N.Y.: Maxwell School of Citizenship and Public Affairs, Syracuse University, 1982), 9-35.

Wilgus, A. Curtis The Historiography of Latin America: A Guide to Historical Writing, 1500-1800 (Metuchen, New Jersey: The Scarecrow Press, 1975).

Past Imperfect 